\title{
Factors Affecting Work-Life Balance in Technology Era
}

\author{
Husain Nurisman*, Dian Surya Sampurna \\ Department of Management \\ Sekolah Tinggi Ilmu Ekonomi Indonesia \\ Jakarta, Indonesia \\ *husain_nurisman@stei.ac.id,dian_surya_sampurna@stei.ac.id
}

\begin{abstract}
Work-Life Balance began to develop in the twentieth century, especially in women who have difficulty balancing family responsibility and work duties. With the end of the 21st century, this problem is not limited to women but occurs to men and their partners, who work and have difficulty fulfilling both roles (family and work). One of the causes of disruption in fulfilling these roles is the existence of technology. Technology can make someone disturbed because when they are with their families they are still doing work mattres. It can cause conflict in the family or at work (work-family conflict) or it can also be caused by job stress (Job Stress). This research was conducted to determine the effect of work to family conflict and family to work conflict on work-life balance and job stress is used as a mediating factor affecting Work-Life Balance. This research also compares the effects that occur in men and women. By using 206 data of employees domiciled in JABODETABEK as the sample and applying a parsial least square - structural equation model (PLSSEM) to analyze the data, this study tested five hypotheses. The results showed two important findings: [1] Work to family conflict can affect work-life balance even though job stress has no influence in mediating work-life balance. [2] Gender is not able to moderate the influence of Work to Family Conflict, Family to Work Conflict on Work-Life Balance through Job Stress. It implies that men and women have the same influence in achieving work-life balance.
\end{abstract}

Keywords: work-life balance, work to family conflict, family to work conflict, job stress, technology era, gender

\section{INTRODUCTION}

Work-life balance is the ability of individuals to fulfill work or family needs in terms of work responsibilities or other activities [1] or can be interpreted as a balance between work and family in order to fulfill the expectations of the role given and negotiated between individuals and partners related to their role in the realm of work and family [2]. Balance is a subjective concept in describing the satisfaction of one's relationship with life and work so that the more balanced a person's life is, the person will be happier. Work-life balance refers to the balance between work and non-work, which includes non-work is family and personal life.

Work-Life Balance developed in the twentieth century, especially in women who have difficulty balancing family responsibility and work duties. With many women working, a policy was created to facilitate their efforts to balance work and family roles. With many women working, a policy was created to facilitate their efforts to balance work and family roles. With the end of the $21 \mathrm{st}$ century, this problem is not limited to women but occurs to men and their partners who work and have difficulty fulfilling both roles (family and work). One of the causes of the difficulty of fulfilling these is the existence of technology that can make a person continue to do they work even if they are with their family or even at work they are still busy doing they family business. The human resources research states that there is a relationship between work-life balance with job satisfaction, family satisfaction, productivity, organizational performance, psychological well-being, organizational commitment, health and stress [3]. Work-life balance is also related to employee retention, job satisfaction, individual commitment to the organization (work roles) and related to better marriage (family roles), family satisfaction and better family performance [4].

Of the various definitions of Work Life Balance, it can be categorized into two things, (1) involvement of roles in various roles in work and life, and (2) minimizing conflicts between work and life. The results of Work-Life Balance related to work are job satisfaction, organizational commitment, absence. and those related to life (non-work) are family satisfaction, life satisfaction, satisfaction with the availability of free time [5].

A survey submitted by portalhr.com states that the majority of workers in Hong Kong (62\%) and Indonesia (73\%) feel themselves unhappy, due to lack of opportunities in career development, an unpleasant work environment and an absence of balance between Work-life [6]. Another important factor in Work-Life Balance is demographic factors, especially in terms of gender. From the research that has been done, conflicts in Work-Life Balance are more common in women compared to men, women who are married compared to those who are not married, a mother who has a small child experiences conflict with Work-Life Balance more than a mother who has an older child [3]. In a study examining the relationship between gender and Work-Life Balance in terms of dimensions of work disruption and personal life as well as the presence or absence of a significant relationship to the dimensions of personal life disruption with work, get the results that the role of gender is very influential on Work-Life Balance in personal life the cause of which is conflict at work [7], or also called WorkFamily Conflict. 
Work-Family Conflict is a conflict between roles where is pressure between family roles and work roles does not support each other in some ways, meaning that participation in family or work roles becomes more difficult [8]. Conflict can be 2way, that are work demands can interfere with family responsibilities (work to family conflict) and personal and family demands can interfere with work (family to work conflict). Work-family conflict can also be associated as Stress, depression which has a negative effect on mental [9]. Work and family conflicts can happen to anyone, both men and women, but women are more prone to conflict than men, because women spend more time with family and work [10]. Conflicts that occur at work and family will be directly related to stress and stress levels for women who work are greater than women who do not work [11], because working women has more pressure that requires performing different roles and responsibilities both roles at work and home [12]. Employees who are trying to fulfill work responsibilities are increasing and at the same time are trying to fulfill family roles and responsibilities, these employees are struggling with stress and family-work conflicts. Reducing work stress can reduce the level of family-work conflict [13].

Job Stress can be defined as a dangerous emotional and physical response and occurs when job requirements do not meet the needs, resources or abilities of employees [12]. Job Stress can arise due to workload, working conditions and management expectations that cause tension [14]. Stress can also be interpreted as a condition that affects physical and psychological tension, emotions, thought processes, and work behavior, so that stress can stimulate excessive psychological or physical reactions [15]. Stress that occurs in the workplace is usually caused by attachment to work, anarchic situations and relationships between employees [16] and can also be caused by work and excessive responsibilities [7].

\section{LITERATURE REVIEW AND HYPOTHESIS DEVELOPMENT}

\section{A. Work-Life Balance}

Definition of Work-Life Balance can be categorized into 2 main dimensions, i.e. (1) role involvement in various roles in work and life and (2) conflict between work role and non-work role [16]. Work-life balance can be influenced by, (1) Technology, which is technological innovation that is very fast causing changes in perception in work-life balance. With mobile technology, employee flexibility in speed, place and time of day. Besides technology can improve efficiency at work, technology can also make people feel controlled so they feel they never stop working [3]. Technology can make people willing to work in their personal time and can also use their work time for their personal affairs, but there are some people who want a clear separation of personal and work life and consider it detrimental so that it can cause stress both at work and in his personal life [17]. (2) Employee Expectations, are employee expectations for a balance of time to meet the needs of work and personal life [18]. (3) Work-Life realization, is the realization of the expected work and life balance.

At the beginning of the 21 st century Technology innovation has increased the speed and accuracy of work for employees. Cellular Technology brings flexibility to employees in the form of controlling speed, location, and time or day. Technology has aroused the feelings of employees because they never quit the job because of increased expectations [3]. With technology, the company will easily connect with its employees even though they are far from the office and for the company it will increase the productivity of its employees [19]. On the other side, there are some people who want a clear dealing of time, so if a violation occurs it will make them feel disadvantaged [17]. With technology, the family is no longer a place of protection, recreation and entertainment that is free from supervision but controlled by work electronically [20].

For women, work-life balance is more difficult than men because women have more burdens and responsibilities towards the family. This uneven burden makes it difficult for women to balance work and family [21]. But with technology can make it easier for women to balance their work and life. They can do work while in the family or vice versa they can easily carry out control at home using existing technology. so with technology, the boundary between work and life will be slightly reduced, both for men and women so it is necessary to redefine the limits of work-life balance in this technological era.

\section{B. Work-Family Conflict}

Work-family conflict can be defined as a form of conflict between roles where the stress of the role of the work domain (work conflict) and the family domain (family conflict) is not balanced, meaning the extent to which a person experiences role pressure that is incompatible with the work domain or family domain [22]. According to Greenhaus and Beutell [23] There are 3 main forms of work-family conflict, i.e. (1) Timebased conflict, is a conflict arising from the need for time, the time used to carry out one role both family and work can reduce the time to perform other roles. Time-based conflict can take two forms, firstly the time pressure associated with membership in one role so that it makes it physically impossible to fulfill the expectations of another role, secondly the pressure can also produce a liking for a role even when someone physically tries to fulfill another role. (2) Strain-based conflict, is a conflict that arises as a result of pressure arising from one role influencing individuals in performing other roles. Strain-based conflict is very consistent with the dimensions of fatigue, so fatigue in one role will affect other roles meaning the pressure created by someone will be difficult to meet the demands of the other. (3) Behavior-based conflict, arises from a pattern of behavioral intention that is the difference between the pattern of behavior desired by both parts (work or family) [24]. There is no empirical research that directly assesses behavior-based conflict, maybe if someone is unable to adjust the behavior to what is expected to be a different role, it is likely that conflict will occur.

\section{Job Stress}

Stress is defined as an individual's psychological response to a situation where something is at stake and where the situation exceeds that individual's capacity or resources [7]. Job stress is conceptualized as the relationship between work and people [25]. These relationships are those that arise from excess workload, time pressure and additional responsibilities 
equal opportunities for parts in each element (member) of the population to be selected as sample members [28]. development or achievement (also called stress challenges). Stress arises when individuals doubt their ability to deal with threats to their well-being and their ability to meet demands accurately, so that conflicts that occur between work demands and levels of control are carried out to meet these demands resulting in dangerous mental and physical responses that are defined as job stress [26].

\section{Research Model and Hypothesis Development}

According to the review, this study proposes the research model and hypotheses are as shown in Figure 1:

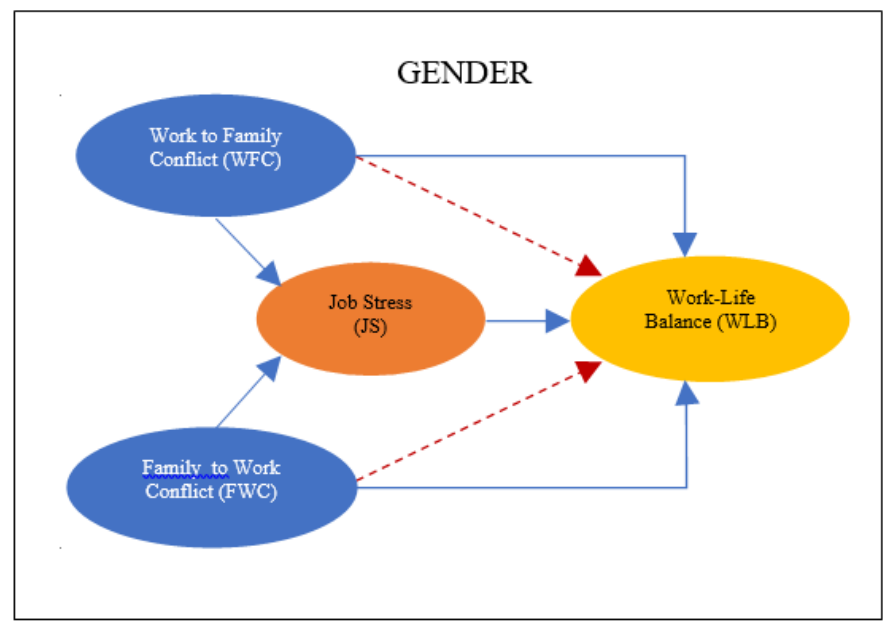

Fig. 1. Research model.

According to the above model, the hypotheses are:

$\mathrm{H}_{1}$ : Work to family conflict positively affect work-life balance.

$\mathrm{H}_{2}$ : Family to work conflict positively affect work-life balance.

$\mathrm{H}_{3}$ : Work to family conflict and family to work conflict positively affect work-life balance.

$\mathrm{H}_{4}$ : Job stress is able to mediate the effect of work to family conflict and family to work conflict on work-life balance.

$\mathrm{H}_{5}$ : Gender is able to moderate the influence of work to family conflict and family to work conflict on work-life balance.

\section{METHOD}

\section{A. Respondent}

Respondents in this study are male and female employees who live in JABODETABEK (Jakarta, Bogor, Depok, Tanggerang and Bekasi) with 206 respondents [27]. The measurement method uses a questionnaire with a Linkert scale from 1 (strongly disagree) to 4 (strongly agree). The questionnaire is divided into 4 parts: work to family conflict variable consists of 12 items, family to work conflict variable consists of 12 items, job stress consists of 13 items and worklife balance consists of 11 items. The sampling method used is probability sampling, It's a sampling technique that provides

\section{B. Measure}

This study applied a reliability and validity test by using Cronbach Alpha and Confirmatory Factor Analysis. Validity test used in this study was convergent validity using Standard Loading Factor (SLF) and the minimal criteria for all the loading factors were statistically significant. The reference limit value of loading factor is $>0.70$ is recommended (SLF> 0.5). Reliability test used was the Combach's Alpha, Composite Reliability (CR) and Average Variance Extracted (AVE). The benchmark value for instrument reliability was $0.7(\alpha), 0.5$ (AVE) and 0.7 (CR), respectively [29,30]. The results of validity and reliability test as show in Table 1 :

TABLE I. RELIABILITY AND VALIDITY RESULT

\begin{tabular}{|l|l|l|l|}
\hline \multicolumn{1}{|c|}{ Variable } & \multicolumn{1}{c|}{$\begin{array}{c}\text { Combach's } \\
\text { Alpha }\end{array}$} & CR & AVE \\
\hline FWC & 0.936 & 0.954 & 0.597 \\
\hline JS & 0.954 & 0.960 & 0.688 \\
\hline WFC & 0.929 & 0.941 & 0.640 \\
\hline WLB & 0.793 & 0.877 & 0.706 \\
\hline
\end{tabular}

Validity Test can also be done by using discriminant validity test by comparing each AVE square root to the correlation value between constructs. The results of validity test as show in Table 2:

TABLE II. DISCRIMINANT VALIDITY RESULT

\begin{tabular}{|l|l|l|l|l|}
\hline & \multicolumn{1}{|c|}{$\mathbf{1}$} & \multicolumn{1}{|c|}{$\mathbf{2}$} & $\mathbf{3}$ & $\mathbf{4}$ \\
\hline (1) FWC & $\mathbf{0 . 7 6 6}^{*}$ & & & \\
\hline (2) JS & 0.605 & $\mathbf{0 . 8 2 9} *$ & & \\
\hline (3) WFC & 0.622 & 0.790 & $\mathbf{0 . 8 0 0 *}$ & \\
\hline (4) WLB & 0.460 & 0.494 & 0.617 & $\mathbf{0 . 8 4 0} *$ \\
\hline
\end{tabular}

\section{Data Analysis}

After the data is collected, data analysis was performed to test the hypotheses that have been submitted. Data analysis using SEM (Structured Equation Modeling), PLS (Partial Least Squares)

\section{Result}

This results showed that male was the dominant respondents (56.31\%) compared to female (43.69\%). Respondents work as private employees $(62.14 \%)$, government employees (17.69\%), BUMN employees (13.11\%) and entrepreneurs $(6.8 \%)$. Ages of respondents was, less than 23 $(4.37 \%), 24$ to $38(45.15 \%), 39$ to $51(43.69 \%)$ and 52 to 73 $(6.8 \%)$ with more than half were married $(73.33 \%)$. The respondents' educational background was university level $(92.72 \%)$.

After the data is collected, data analysis was performed to test the hypotheses that have been submitted. Data analysis using SEM (Structured Equation Modeling), PLS (Partial Least Squares) 


\section{RESULTS AND DISCUSSION}

\section{A. Results}

After the assessment of measurement model, this study has executed the bootstrapping approach with a sub-sample of $5000[23,24]$ to examine the relationship between exogenous latent constructs and endogenous latent construct. Figure 2 depicted the significance results of independent and dependent variables.

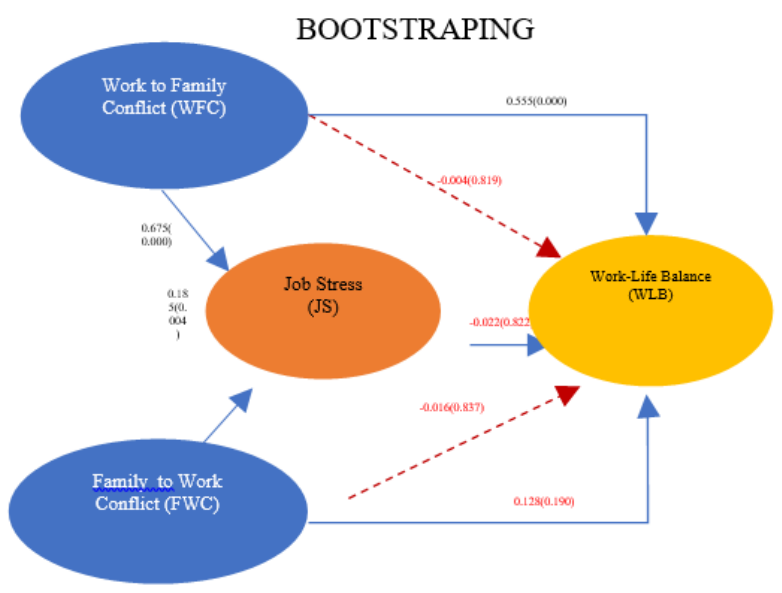

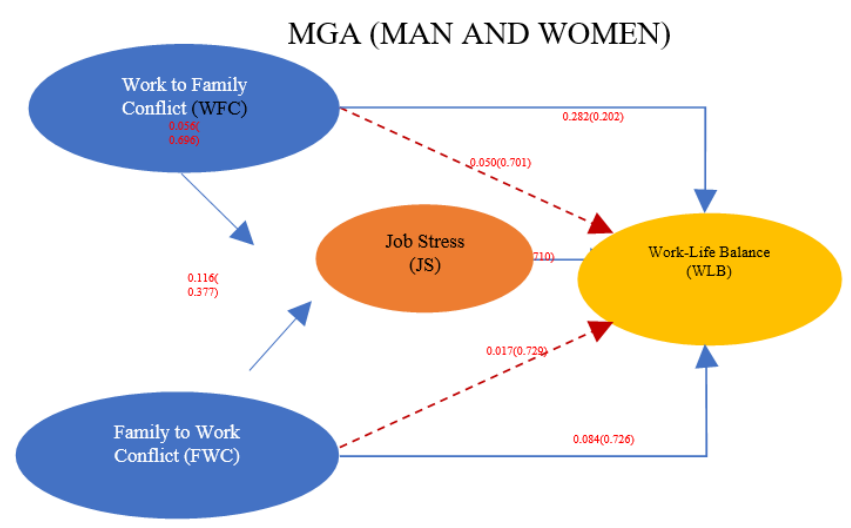

Fig. 2. Structural model result.

After the assessment of measurement models, this study has executed the bootstrapping approach to examine the relationship between exogenous latent constructs and endogenous latent constructs. The result of this study (see Tabel 3) is the all relationships were rejected because have a pvalue greater than 0.05 , except for the relationship between Work-family conflict to work-life balance (H1) which had a significant relationship ( $\mathrm{p}$-value <0.05). All hypothesized relationships are presented in Table 3.

TABLE III. STRUCTURAL MODEL RESULT

\begin{tabular}{|c|c|c|c|c|c|c|}
\hline Hypotheses & Relationship & Path Coefficient & Std Error & T Value & P VALUE & Decisions \\
\hline $\mathrm{H} 1$ & WFC-WBL & 0.555 & 0.555 & 4.827 & 0.000 & Accepted \\
\hline $\mathrm{H} 2$ & FWC-WBL & 0.128 & 0.096 & 1.332 & 0.190 & Rejected \\
\hline H3 & $\begin{array}{l}\text { WFC-WBL } \\
\text { FWC-WBL }\end{array}$ & $\begin{array}{l}0.555 \\
0.128\end{array}$ & $\begin{array}{l}0.555 \\
0.096\end{array}$ & $\begin{array}{l}4.827 \\
1.332\end{array}$ & $\begin{array}{l}0.000 \\
0.190\end{array}$ & Rejected \\
\hline $\mathrm{H} 4$ & $\begin{array}{l}\text { WFC-JS } \\
\text { FWC-JS } \\
\text { JS-WBL }\end{array}$ & $\begin{array}{l}0.675 \\
0.185 \\
-0.022 \\
\end{array}$ & $\begin{array}{l}0.058 \\
0.065 \\
0.097\end{array}$ & $\begin{array}{l}11.729 \\
2.863 \\
0.227 \\
\end{array}$ & $\begin{array}{l}0.000 \\
0.004 \\
0.822 \\
\end{array}$ & Rejected \\
\hline $\mathbf{H}_{5}$ & $\begin{array}{l}\text { WFC-WBL* } \\
\text { WFC-JS* } \\
\text { FWC-WBL* } \\
\text { FWC-JS* } \\
\text { JS-WLB* }\end{array}$ & $\begin{array}{l}0.084 \\
0.116 \\
0.282 \\
0.056 \\
0.077\end{array}$ & & $\begin{array}{l}0.351 \\
0.885 \\
1.280 \\
0.392 \\
0.373\end{array}$ & $\begin{array}{l}0.726 \\
0.377 \\
0.202 \\
0.696 \\
0.710\end{array}$ & Rejected \\
\hline
\end{tabular}

\section{B. Discussion}

This study aims to determine the factors that influence Work-life balance and ensure its influence on gender differences so that companies can identify things that affect Work-life balance. The measurement model analysis shows the all variables fulfil the validity and reliability criteria that have been required by PLS-SEM, the results are obtained only hypothesis 1 that supports the proposed hypothesis, the rest are hypothesis 2 , hypothesis 3 , hypothesis 4 and hypothesis 5 do not support the proposed hypothesis, its means $\mathrm{H} 1$ is a hypothesis that supports employees to be able to balance their work and personal life.

Based on results of the hypothesis 1 shows that there is a significant relationship between Work to Family Conflict and Work-Life Balance. This means, the conflict from work to family conflict is very influential on the creation of work and life balance so that the physical presence of an employee in the middle of his family is needed and technological media cannot replace it. An employee needs to balance work and family by making sure the work is done effectively and productively and the family can be well maintained. But unfortunately this is not easy to do, resulting in work conflicts to the family. In a study it was revealed that $75 \%$ of women workers with family's experience work and family conflicts every day [31]. The effects that occur in these conflicts can reduce the level of employee productivity, dissatisfaction at work, until the emergence of bad behavior (e.g. drunk, stress, etc.). To reduce the level of work conflict to the family is to make flexible time at work, by managing themselves when to work and when to take care of the family. Another way that can be done is to create an organizational culture and company policies that support the creation of a balance between work. Technology can also reduce the level of conflict in work to the family. With technology the boundaries between work and family are narrow, a worker can keep doing work even though he is at home and while working they can keep communicating and doing family matters. 
Based on hypothesis 5, it shows that gender is not able to moderate the influence of Work to Family Conflict, Family to Work Conflict, Job Stress and Work-Life Balance. According to research, female workers are more difficult to balance work and life compared to male workers, because women have more duties that are in addition to having responsibilities in work, they are also responsible for taking care of the family so it will be difficult for them to divide well timed. But with technology, it can help women to take care of their families by not leaving their existing jobs, or when they are with their families they can easily carry out their work. So this technology can change the paradigm of differences between men and women in achieving work and life balance.

\section{CONCLUSION}

Work business can increase conflict in the family and will eventually create an imbalance between life and family. With the availability of time and togetherness with the family remains an important factor in the creation of Work-life balance. The availability of technology is not enough to replace the presence of someone in the middle of his family. But with technology both men and women have the same effect on Work to Family Conflict and Family to Work Conflict on Work-Life Balance. This means both men and women have the same level of influence in creating work-life balance.

\section{REFERENCES}

[1] L.P. Parkes and P.H. Langford, "Work-life balance or work-life alignment? A test of the importance of work-life balance for employee engagement and intention to stay in organisations," Journal of Management and Organization. Lyndfield: Australian and New Zealand Academy of Management (ANZAM), vo. 14, no. 3, pp. 267-284, 2008.

[2] J.G. Grzywacz and D.S. Carlson, "Conceptualizing Work-Family Balance: Implications for Practice and Research," Advances in Developing Human Resources, vol. 9, no. 4, pp. 455-471, 2007.

[3] O.F. Khan and A.I. Fazili, "Work Life Balance : a Conceptual Review," Journal of Strategic Human Resource Management, 2002

[4] L.S. Pheng and B.K.Q. Chua, "Work-Life Balance in Construction," Management in the Built Environment, pp. 7-17, 2019.

[5] M.J. Sirgy and D.J. Lee, "Work-Life Balance: an Integrative Review," Applied Research in Quality of Life. Applied Research in Quality of Life, vol. 13, no. 1, pp. 229-254, 2018.

[6] PortalHR.com, Survey Hubungan Baik Atasan Bawahan Sumber Happy di Tempat kerja [Online] Retrieved from: https://portalhr.com/peoplemanagement/employee-relations/survey-hubungan-baik-atasanbawahan-sumber-happy-di-tempat-kerja/ (Accessed date april, 25,2019)

[7] X. Chang, Y. Zhou, C. Wang \& C. de Pablos Heredero, "How do workfamily balance practices affect work-family conflict? The differential roles of work stress," Frontiers of Business Research in China, vol. 11, no. 1, 2017.

[8] P. Walia, "Gender and Age as Correlates of Work-Life Balance," Journal of Organization and Human Behaviour, vol. 4, no. 1, 2016.

[9] S.J. Jang and A. Zippay, "The Juggling Act: Managing Work-Life Conflict and Work-Life Balance," Families in Society: The Journal of Contemporary Social Services, vol. 92, no. 1, pp. 84-90, 2013.

[10] K. Dartey-Baah, "Work-family conflict, demographic characteristics and job satisfaction among ghanaian corporate leaders," International Journal of Business, vol. 20, no. 4, pp. 292-307, 2015.

[11] S.A.B. Panatik, A. Rajab, I.M. Shah, H.A. Rahman, R.M. Yusoff \& S.K.B.Z. Badri, "Work-Family Conflict, Stress and Psychological Strain in Higher Education," International Conference on Education and Management Innovation, vol. 30, pp. 67-71, 2012.
[12] S.S.A. Kazmi, H. Muhammad, U. Mehboob, R.M. Syeikh and A.K. Muhammad, "Impact of Job Stress on Work Family Conflict : a Case Study of Bankers of Private Sector Banks in Peshawar, Pakistan," City University Research Journal, (Special Issue: AIC), pp. 195-205, 2018.

[13] M. Hashim and F. Hameed, "Human resource management in 21st Century: Issues \& challenges \& possible polutions to attain competitiveness," International Journal of Academic Research in Business and Social Sciences, vol. 2, no. 9, pp. 44-52, 2012.

[14] A. Shukla and R. Srivastava, "Development of short questionnaire to measure an extended set of role expectation conflict, coworker support and work-life balance: The new job stress scale," Cogent Business and Management. Cogent, vol. 3, no. 1, pp. 1-20, 2016.

[15] N. K.Suryani, I.W.G. Sarmawa and M. Wardana, "Work family conflict, job stress and job performance (Case study Spa employee in Bali)," European Journal of Business and Management www.iiste.org, vol. 6, no. 32, pp. 189-196, 2014.

[16] M.J. Sirgy and D.J Lee, "Work-Life Balance: an Integrative Review," Applied Research in Quality of Life. Applied Research in Quality of Life, vol. 13, no. 1, pp. 229-254, 2018

[17] T. Nam, "Technology Use and Work-Life Balance," Applied Research in Quality of Life, vol. 9, no. 4, pp. 1017-1040, 2014.

[18] M. Tausig and R. Fenwick, "Unbinding time: Alternative work schedules and work-life balance," Journal of Family and Economic Issues, vol. 22, no. 2, pp. 101-119, 2001.

[19] G. Roy, "Impact of Mobile Communication Technology on the Work Life Balance of Working Women-a Review of Discourses," The Journal -Contemporary Management Research, vol. 10, no. 1, pp. 79-101, 2016.

[20] T.A. Adisa, G. Gbadamosi and E.L. Osabutey, "What happened to the border? The role of mobile information technology devices on employees work- life balance," Management Research Review, vol. 39, no. 12, pp. 1663-1694, 2016.

[21] S. Rehman and M.A. Roomi, "Gender and work-life balance: A phenomenological study of women entrepreneurs in Pakistan," Journal of Small Business and Enterprise Development, vol. 19, no. 2, pp. 209228, 2012.

[22] R.E. Kopelman, J.H. Greenhausand and T.F. Connolly, "A model of work, family, and interrole conflict: A construct validation study," Organizational Behavior and Human Performance, vol. 32, no. 2, pp. $198-215,1983$.

[23] J.H. Greenhaus and N.J. Beutell, "Sources of Conflict Between Work and Family Roles," Academy of Management review, vol.10, no. 1, pp. 76-88, 1985.

[24] N.P. Noviati, "Correlation between Work-Family Conflict and Job Stress among Government Public Service Employees: The Moderating Role of Psychological Capital," GSTF Journal of Psychology, vol. 3, no. 1, pp. 8-15, 2016

[25] S. Sur and E.S. Ng, "Extending Theory on Job Stress: The Interaction Between the "Other 3" and "Big 5" Personality Traits on Job Stress," Human Resource Development Review, vol. 13, pp. 79-101, 2014.

[26] K. Saeed and Y.A. Farooqi, "Examining the relationship between work life balance, job stress and job satisfaction among university teachers: A case of University of Gujrat" International Journal of Academic Research in Progressive Education and Development, vol. 3, no. 4, pp. 36-46, 2014.

[27] J.F. Hair Jr, G.T.M. Hult, C. Ringle and M.A. Sarstedt, Primer On Partial Least Squares Structural Equation Modeling (PLS-SEM). Singapore: SAGA Publication Asia-Pasific, 2016.

[28] J. Hartono, Metodologi Penelitian Business: Salah Kaprah dan Pengalaman-Pengalaman. Yogyakarta: Penerbit BPFE, 2010.

[29] G. Imam and Latan, Partial Least Squares, Konsep, Teknik dan Aplikasi Menggunakan Program SmartPLS 3.0 Untuk Penelitan Empiris. Semarang: UNDIP, 2014

[30] F. Hair "Partial least squares structural equation modeling (PLS- SEM)," European Business Review, vol. 26, no. 2, pp. 106-121, 2014.

[31] M. C. Marchese, et al. "Conflict : A Virtue Ethics Analysis," Journal of business Ethics, vol. 40, no. 2, pp. 145-154, 2012. 